\title{
ANALISIS KEBIJAKAN PEMERINTAH JAWA BARAT DI MASA PANDEMI COVID-19 DALAM PERSPEKTIF EKONOMI
}

\author{
Rahmi Widia Aliani Abubakar
}

Fakutas Ekonomi dan Bisnis Islam, Universitas Suryakancana rahmiekonomisyariah@gmail.com

\begin{tabular}{l|l|l|} 
Masuk: Juli 2021 & Penerimaan: Agustus 2021 & Publikasi: September 2021 \\
\hline
\end{tabular}

\begin{abstract}
Abstrak
Penelitian ini bertujuan untuk menganalisis kebijakan pemerintah Jawa Barat dalam upaya pertumbuhan ekonomi daerah dimasa Pandemi Covid-19. Terdapat 9 skala prioritas kebijakan diantaranya adalah (1) Akses pendidikan untuk semua; (2) Desentralisasi layanan kesehatan; (3) Pertumbuhan ekonomi umat berbasis inovasi; (4) Pengembangan destinasi dan infrastruktur pariwisata; (5) Pendidikan agama dan tempat ibadah juara; (6) Infrastruktur konektivitas wilayah; (7) Gerakan Membangun Desa (Gerbang Desa); (8) Subsidi gratis golongan ekonomi lemah; dan (9) Inovasi pelayanan publik dan penataan daerah. Penelitian ini menggunakan pendekatan kualitatif dengan metode penelitian case studies, dimana 9 kebijakan pemerintah dianalisis dengan melihat realisasi pelaksanaan kebijakan pemerintah dilapangan. Data diperoleh dari RKPD yang dipaparkan dalam acara BAPPEDA Jabar. Hasil penelitian yang dicapai melalui analisis kualitatif meliputi keselarasan kebijakan pemerintah dengan praktek dilapangan.
\end{abstract}

Kata Kunci : Analisis Kebijakan, Pertumbuhan Ekonomi,Pemerintah Jawa Barat

\begin{abstract}
$\underline{\text { Abstract }}$
This study aims to analyze the policies of the West Java government in an effort to grow the regional economy during the Covid-19 pandemic. There are 9 policy priority scales including (1) Access to education for all; (2) Decentralization of health services; (3) The economic growth of the people based on innovation; (4) Development of tourism destinations and infrastructure; (5) Religious education and places of worship are champions; (6) Regional connectivity infrastructure; (7) Village Building Movement (Village Gate); (8) Free subsidies for weak economic groups; and (9) Public service innovation and regional arrangement. This research uses a qualitative approach with case studies research methods, where 9 government policies are analyzed by looking at the realization of the implementation of government policies in the field. The data was obtained from the RKPD which was presented at the West Java BAPPEDA event. The research results achieved through qualitative analysis include the alignment of government policies with practice in the field.
\end{abstract}

Keywords : Policy Analysis, Economic Growth, West Java Government

\section{A. PENDAHULUAN}

Covid 19 adalah masalah global yang harus diselesaikan bersama, virus ini membunuh semua aspek kehidupan. Pemerintah Jawa Barat sudah melakukan 
perannya demi mencegah penyebaran virus salah satunya dengan diterapkannya PSBB di setiap kabupaten/kota. Pada data pikobar jabar prov Provinsi Jawa Barat memberlakukan PSBB dimulai dari tanggal 15 april 2020.

Pemerintah Jawa Barat melalui Nota Kesepakatan Bersama Antara Kepala Daerah dan Pimpinan DPRD Jabar terhadap Rancangan Kebijakan Umum Anggaran-Prioritas Plafon Anggaran Sementara (RKUA-PPAS) APBD Provinsi Jabar Tahun Anggaran 2021 dalam rangka memutuskan untuk focus secara khusus pada dampak pandemi diantaranya bidang kesehatan, sosial dan ekonomi.

Terdapat sembilan prioritas pembangunan yang akan dilakukan oleh pemerintahan Jawa Barat diantaranya adalah: (1) Akses pendidikan untuk semua; (2) Desentralisasi layanan kesehatan; (3) Pertumbuhan ekonomi umat berbasis inovasi; (4) Pengembangan destinasi dan infrastruktur pariwisata; (5) Pendidikan agama dan tempat ibadah juara; (6) Infrastruktur konektivitas wilayah; (7) Gerakan Membangun Desa (Gerbang Desa); (8) Subsidi gratis golongan ekonomi lemah; dan (9) Inovasi pelayanan publik dan penataan daerah.

Penurunan dalam ekonomi adalah masalah krusial yang harus diselesaikan. Pertumbuhan ekonomi menjadi alat ukur bagi kemajuan bangsa. Jika suatu bangsa ekonominya maju maka sektor yang lain juga akan mengikuti.

Pemerintaham Jawa Barat dihadapkan pada kondisi pertumbuhan ekonomi yang menurun akibat pandemi. Pada data BPS Jawa Barat menyebutkan bahwa sekitar $-2,44 \%$ perekonomian di Jawa Barat menurun selama pandemi. Data ini dibandingkan dengan data pada tahun 2019. Pada sektor lain di Jawa Barat perekonomian masih menunjukan angka yang positif diantaranya adalah Lapangan usaha informasi dan komunikasi, pengadaan air, pengelolaan sampah, limbah dan daur ulang.

\section{B. METODE PENELITIAN}

Metode penelitian kualitatif case studies dijelakan oleh Polite yaitu metode penelitian yang digunakan untuk mencapai tujuan penelitian. Data diperoleh dari metode observasi analisis dan data instansi maupun analisis secara langsung dikehidupan bermasyarakat. 


\section{HASIL DAN PEMBAHASAN}

\section{Kebijakan Pemerintah}

Irfan Islamy menyebutkan bahwa kebijaksanaan adalah suatu taktik dan strategi yang diarahkan untuk mencapaisuatu tujuan. Sedangkan, James E Anderson, mendefinisikan kebijakan itu adalah serangkaian tindakan yang mempunyai tujuan tertentu yang diikuti dan dilaksanakan oleh seseorang pelaku sekelompok pelaku guna memecahkan suatu masalah tertentu.

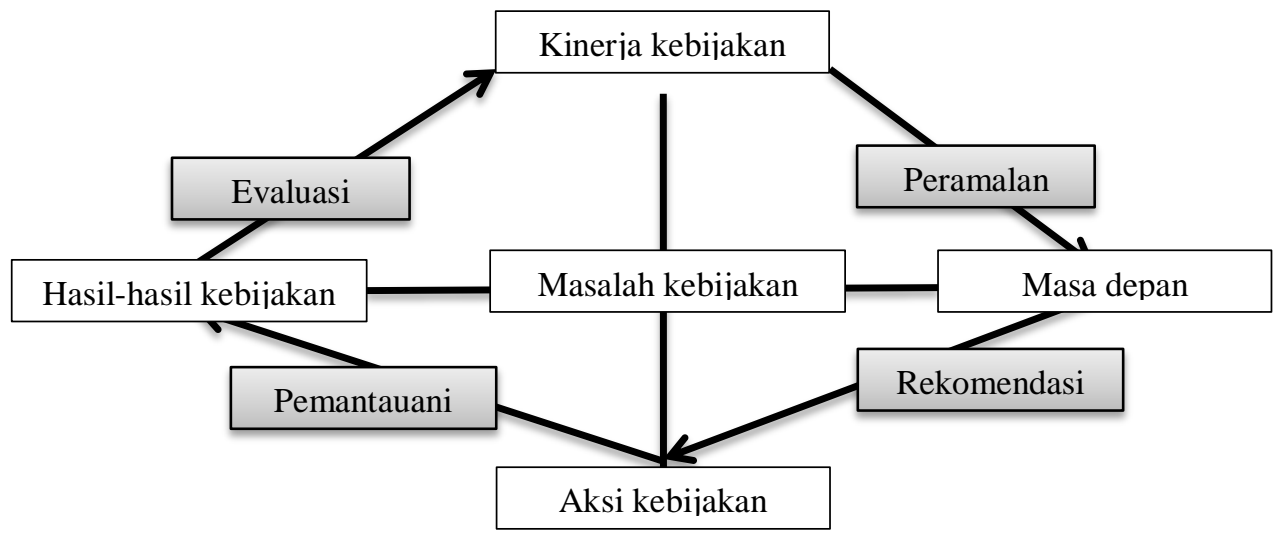

Gambar 1

Analisis kebijakan yang berorientasi pada masalah

Terdapat tiga bentuk analisis kebijakan yang diungkapkan oleh Dunn, yaitu:

a. Analisis kebijakan prospektif adalah analisis kebijakan yang mengarahkan kajiannya pada konsekuensi-konsekuensi kebijakan sebelum suatu kebijakan diterapkan. Model ini dapat disebut sebagai model prediktif.

b. Analisis kebijakan retrospektif adalah analisis kebijakan yang dilakukan terhadap akibat-akibat kebijakan setelah suatu kebijakan diimplementasikan. Model ini biasanya disebut sebagai model evaluatif.

c. Kebijakan integratif adalah bentuk perpaduan antara analisis kebijakan prospektif dan analisis kebijakan retrospektif.

\section{Pertumbuhan Ekonomi}

Pertumbuhan ekonomi menurut sukirno adalah perkembangan kegiatan dalam perekonomian yang menyebabkan barang dan jasa yang diproduksi dalam masyarakat bertambah dan kemakmuran masyarakat meningkat. Prof Kunnet menyebutkan, Pertumbuhan ekonomi adalah kenaikan kapasitas jangka panjang 
dari negara yang bersangkutan untuk menyediakan berbagai barang ekonomi kepada penduduknya.

Menekankan pada kenaikan ekonomi masyarakat, tolak ukur dari kemajuan pertumbuhan ekonomi masyarakat adalah perkembangan kegiatan ekonomi yang terjadi secara terus menerus. Oleh karena itu, pemerintah diharapkan dapat memantau berjalannya kebijakan-kebijakan yang dibuat di wilayah hukumnya serta dapat memagari dengan peraturan-peraturan yang berlaku di masyarakat.

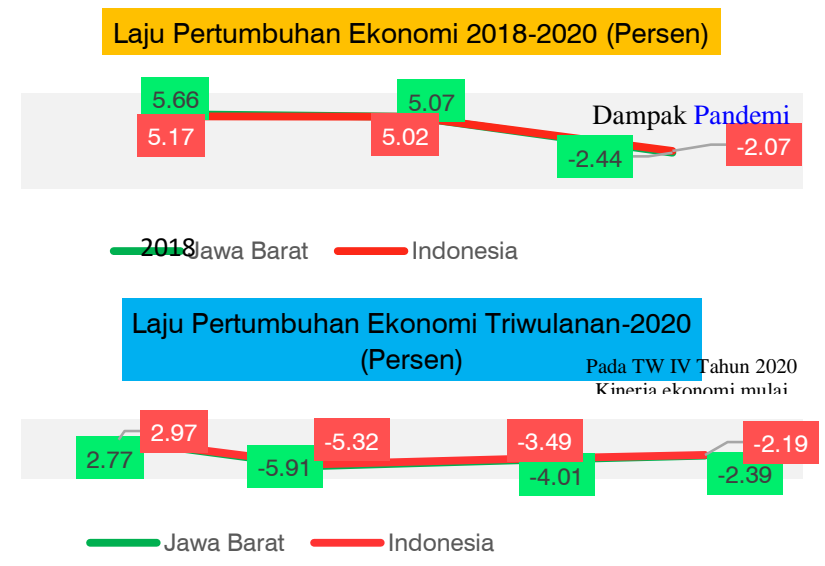

Gambar 2

Laju Pertumbuhan Ekonomi Indonesia dan Jawa Barat (Data BAPPEDA tahun 2021)

Perbedaan data laju pertumbuhan ekonomi Indonesia dan Jawa Barat terlihat adanya penurunan karena dampak pandemi covid-19. Terlihat dari data tahun 2019 data pertumbuhan ekonomi menurun sebanyak -2,44\%. Data perbandingan dengan laju pertumbuhan ekonomi indonesia juga mengalami penurunan selama pandemi terlihat dari data pada gambar paling atas penurunan dari 2019-2020 untuk Indonesia di 2019 mengalami penurunan sebanyak -2,07.

Dari data tersebut terlihat betapa pandemi membuat semua aspek kehidupan terutama ekonomi terkena dampaknya. Banyak korban akibat pandemi menjadikan masyarakat harus melakukan kebiasaan-kebiasaan baru. Pengeluaran yang dilakukan dalam rumah tangga sebelum pandemi dan setelah pandemi tentunya tidak akan sama, kecuali masyarakat dengan pengasilan tetap yang tidak terganggu pandemi. 


\section{Laju Pertumbuhan Ekonomi}

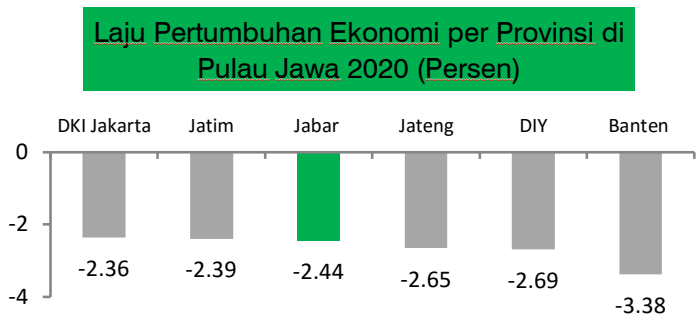

Data BAPPEDA tahun 2021

Gambar 3

Laju Pertumbuhan Ekonomi Perprovinsi di Pulau Jawa

Berdasarkan data di atas diketahui bahwa laju pertumbuhan ekonomi Jawa Barat mengalami penurunan selama masa pandemi yaitu senilai $-2,44 \%$ jauh lebih sedikit dari Provinsi Jawa Timur, dan DKI. Meskipun demikian Jawa tengah, DIY, dan Banten lebih besar angka penurunan pertumbuhan ekonomi akibat pandemi COVID-19.

\section{Tingkat Kemiskinan di Jawa Barat}

\section{Tren Jumlah dan Persentase Penduduk Miskin Provinsi Jawa Barat Tahun 2016-2020}

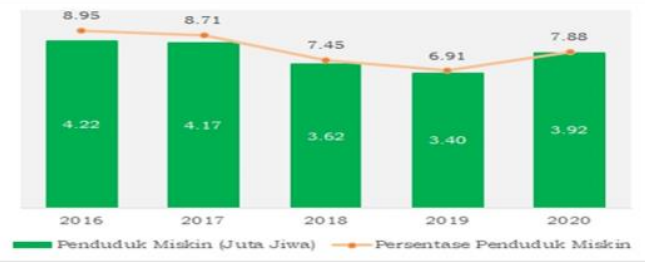

Data BAPPEDA tahun 2021

Gambar 4

Tren Jumlah dan Persentase Penduduk Miskin Provinsi Jawa Barat

Nugroho berpendapat bahwa, kemiskinan dibentuk berdasarkan identifikasi dan pengukuran terhadap sekelompok masyarakat/golongan yang selanjutnya disebut miskin. Selanjutnya Supriatna menyatakan bahwa kemiskinan adalah situasi yang serba terbatas yang terjadi bukan atas kehendak orang yang bersangkutan.

Kemiskinan mengakibatkan berkurangnya kemampuan daya beli masyarakat yang mengakibatkan tidak berjalannya roda ekonomi. Dalam masa 
pandemi sekitar tahun 2019-2020 daya beli masyarakat yang cenderung menurun membuat perusahaan-perusahaan gulung tikar dan imbasnya PHK besar-besaran.

Dari gambar 4 bisa kita lihat bahwa penduduk miskin mengalami peningkatan selama pandemi yaitu sebesar 0,97\% yaitu dari angka 6,91\% ke 7,88\%. Hal tersebut terjadi karena berbagai faktor yaitu : daya beli, kebiasaankebiasaan ekonomi lainnya yang tentunya mempengaruhi.

Ada tiga strategi dasar program menurut Dennis yang bertujuan untuk membantu penduduk miskin yakni:

a. Bantuan disalurkan ke tempat dimana mayoritas orang miskin hidup, melalui program pembangunan desa terpadu atau proyek produksi pelayanan yang berorientasi pada penduduk desa.

b. Bantuan dipusatkan untuk mengatasi cacat standar kehidupan orangorang miskin melalui program kebutuhan dasar manusia.

c. Bantuan dipusatkan pada kelompok yang mempunyai ciri sosio ekonomi yang sama yang mendorong atau mempertahankan mereka untuk terus berkubang di dalam lingkaran kemiskinan melalui proyek yang dirancang bagi masyarakat tertentu.

\section{Kemiskinan menurut Islam}

Masalah kemiskinan dianggap sebagai bagian dari masalah penting yang memiliki pengaruh besar terhadap kehidupan individu dan sosial. Kemiskinan dianggap sebagai sumber berbagai kejahatan dan kegiatan sumbang, dalam hadist dijelaskan :

\section{كَادَ أَنْفَفْرُ يَكُوْنَ كُفْرًا}

Kemiskinan itu dekat kepada kekufuran.

Dalam hadits tersebut dijelaskan bahwa kemiskinan dekat dengan kekufuran karena dikhawatirkan akan banyak kejahatan, perebutan harta, keserakahan, kemusyrikan, menjilat, korupsi dan sebagainya. Kemiskinan dapat membuat orang gelap mata jika tidak dibarengi dengan iman dan sabar.

\section{PEMBAHASAN}

Pandemi yang terjadi tergolong baru yaitu diakibatkan oleh virus COVID19 dengan adanya pandemi masyarakat ini perlu penyesuaian diri terhadap 
kehidupan karena perubahan-perubahan signifikan diantaranya kebiasaan yang berubah termasuk menjalankan ekonomi, kurangnya mobilitas, atau banyaknya pengangguran efek besar PHK karena banyak perusahaan yang bangkrut, UMKM yang tidak jalan lagi dan sebagainya. Pandemi membuat setiap lini kehidupan terkena imbasnya agama, ekonomi, sosial maupun budaya dan adat istiadat.

Pemerintah pusat maupun daerah sudah membuat kebijakan untuk mengurangi kesulitan-kesulitan yang dialami oleh masyarakat. Kebijakan pemerintah ini diantaranya adalah dengan memeberikan santunan berupa uang atau bahan pokok makanan. Akan tetapi pemberian dana ataupun bahan pokok dinilai tidak merata.

Selain dari perbaikan ekonomi masyarakat, pemerintahan Jawa Barat sudah membuat kebijakan-kebijakan yang akan dilakukan untuk menutup kerugian disegala bidang karena pandemi ini. Namun banyak kendala di lapangan yang harus pemerintah ketahui diantaranya kurangnya akses, kurangnya modal masyarakat untuk memulai usaha kembali, tidak adanya arahan dari pemerintah untuk melanjutkan program di masyarakat membuat kurangnya pantauan yang akan memperngaruhi berjalannya program-program dari kebijakan yang disusun.

Dilihat dalam prakteknya di lapangan kehidupan masyarakat di Jawa Barat selain sumber daya manusia yang kurang juga kurangnya modal, dan dukungan dari pemerintah. Pemerintah harusnya bisa memagari pelaksanaan ekonomi masyarakat agar bisa selaras dari hulu ke hilir. Pemerintah memantau dengan seksama bagaimana masyarakat mendapatkan modal, membuat produk, memasarkan dan membuat usaha itu tetap berjalan. Kalaupun masyarakat diberi bantuan untuk modal tanpa kemampuan dan pantauan pemerintah maka ekonomi tidak akan berjalan sesuai dengan yang diharapkan.

Analisis-analisis kebijakan yang dikemukakan oleh Pemerintahan Provinsi Jawa Barat diantaranya adalah :

\section{Akses Pendidikan Untuk Semua}

Seperti yang tercantum dalam tujuan negara Indonesia yang tertuang dalam Pembukaan UUD 1945 salah satunya yaitu mencerdaskan kehidupan bangsa. Usaha yang dilakukan pemerintah dari zaman orde baru sudah dilakukan 
diantaranya wajib belajar 9 tahun yaitu dari usia dasar sampe menengah, tetapi pemerataan pendidikan tetap masih rendah.

Pemerintahan Jawa Barat melalui kebijakan-kebijakan tentang pendidikan merencanakan dalam programnya bahwa pemerintah Jawa Barat akan membebaskan biaya SPP bagi masyarakat Jawa Barat yang bersekolah di Sekolah Menengah Atas (SMA), Sekolah Menengah Kejuruan (SMK) dan Sekolah Luar Biasa (SLB) negeri. Dalam paparan RKPD 2022 BAPPEDA Jawa Barat dijelaskan bahwa pemerintah Jawa Barat mengatur hal tersebut agar akses pendidikan di Jawa Barat lebih merata.

Dalam bahasa arab pendidikan disebut al-tarbiyah, al-ta'lim dan alta'dib. Dari ketiga istilah tersebut terj yang populer digunakan dalam praktek pendidikan Islam adalah terj al-tarbiyah. Pendidikan adalah proses pembinaan akal manusia yang merupakan potensi utama dari manusia sebagai mahkluk yang berfikir.

Jawa Barat adalah daerah luas tidak semua bisa tersentuh tekhnologi, tetapi pemerintah terus berupaya untuk melakukan perbaikan didaerahnya. Dalam website JabarProv.go.id Provinsi Jawa Barat dengan luas 35.377,76 Km2 menurut data SIAK Provinsi Jawa Barat didiami penduduk sebanyak 46.497.175 Juta Jiwa. Pembangunan manusia di Provinsi Jawa Barat terus memperlihatkan perkembangan yang positif sejak tahun 2010. Peningkatan kualitas hidup manusia pada Tahun 2019-2020 mengalami percepatan, dimana untuk capaian IPM Provinsi Jawa Barat tahun 2020 mampu melampaui rata-rata IPM Nasional. IPM Provinsi Jawa Barat tahun 2020 mencapai 72,09, lebih tinggi dari IPM Nasional sebesar 71,94.

\section{Desentralisasi Layanan Kesehatan}

Menurut Levey Loomba, pelayanan kesehatan adalah upaya yang dilakukan oleh suatu organisasi baik secara sendiri atau bersama-sama untuk memelihara dan meningkatkan kesehatan, mencegah dan menyembuhkan penyakit serta memulihkan perseorangan, kelompok dan ataupun masyarakat. Pelayanan Kesehatan yang baik berpengaruh besar terhadap kesehatan masyarakatnya.

Pemerintah Jawa Barat merencanakan memberikan bantuan berupa anggaran Penerima Bantuan Iuran (PBI). Penerima PBI adalah peserta jaminan 
kesehatan bagi fakir miskin dan orang tidak mampu sebagaimana diamanatkan UU SJSN yang iurannya dibayar oleh pemerintah sebagai peserta program Jaminan Kesehatan. Selain dari kebijakan pemerintah yang disusun berupa anggaran yang diberikan pemerintahan daerah Jawa Barat juga memberikan pendidikan untuk pelayanan kesehatan.

Seperti yang dilansir dalam kompas, selain PBI Pemerintah Daerah Provinsi Jawa Barat melalui Dinas Kesehatan Provinsi Jawa Barat akan meluncurkan Mobile Puskesmas (MPUS). Program itu digagas untuk memaksimalkan pelayanan kesehatan hingga pelosok Jawa Barat.

\section{Pertumbuhan Ekonomi Umat berbasis Inovasi}

Pertumbuhan ekonomi adalah kenaikan jangka panjang dalam kemampuan suatu negara untuk menyediakan jenis barang-barang ekonomi kepada penduduknya; kemampuan ini tumbuh sesuai dengan kemajuan teknologi, dan penyesuaian kelembagaan dan ideologis yang dibutuhkannya. Dalam tema RKP Tahun 2022 Pemulihan Ekonomi dan Reformasi Struktural yang disusun Pemprov Jabar 7 susunan yang dijadikan prioritas nasional. Prioritas nasional yang utama adalah memperkuat ketahanan ekonomi untuk pertumbuhan berkualitas dan berkeadilan.

Arah kebijakan pembangunan Provinsi Jawa Barat untuk kabupaten/kota dalam upaya pertumbuhan ekonomi umat yang berbasis inovasi difokuskan pada upaya revitalisasi lahan, dukungan infrastruktur, pemanfaatan ilmu pengetahuan dan teknologi, serta pengembangan sumber daya manusia. Disamping itu dalam kaitannya dengan inovasi-inovasi baru, penting juga dilakukan upaya untuk meningkatkan kapasitas dan keterampilan angkatan kerja yang berbasis digital dan teknologi untuk memenuhi kebutuhan pasar serta mengembangkan inkubator bisnis.

\section{Pengembangan destinasi dan infrastruktur pariwisata}

Pengembangan pariwisata adalah suatu usaha untuk mengembangkan atau memajukan objek wisata agar, objek wisata tersebut lebih baik dan lebih menarik ditinjau dari segi tempat maupun benda-benda yang ada didalamnya untuk dapat menarik minat wisatawan untuk mengunjunginya. 
Kebijakan dalam pariwisata yang digaungkan pemerintahan Jawa Barat diantaranya :
a. Pengembangan destinasi wisata;
b. Peningkatan promosi pariwisata;
c. Peningkatan event seni, budaya dan olahraga;
d. Insentif paket wisata di destinasi prioritas;
e. Peningkatan ketersediaan sarana prasarana pendukung (amenitas);
f. Pengembangan kualitas ekonomi kreatif;

Dalam Kompas.com dilansir, Pemerintah Provinsi Jawa Barat punya rencana mengembangkan 76 destinasi wisata baru berbasis alam yang ada di 21 kabupaten/kota di wilayahnya.

Dalam waktu dekat, pihaknya juga mencoba memfinalisasikan kerja sama pengembangan pariwisata di Kawasan Ciater, Kabupaten Subang. "Ciater ini puncaknya Bandung, udaranya sejuk, hamparan teh bagus, pemandangan indah.

\section{Pendidikan Agama dan Ibadah Juara}

Islam sebagai pandangan hidup yang berakar pada sumber-sumber illahiyah. Islam berdasar pada norma dan etika hidup manusia, dalam islam ada cara dan aturan dalam menjalankan kehidupan sehari-hari. Aturan-aturan dan ruh dalam agama islam disampaikan dalam pendidikan agama islam.

Pendidikan Islam adalah upaya membimbing, mengarahkan, dan membina peserta didik yang dilakukan secara sadar dan terencana agar terbina suatu kepribadian yang utama sesuai dengan nilai-nilai ajaran Islam.

Mengingat pentingnya pendidikan agama, pemerintahan Jawa Barat membuat tiga program unggulan yaitu :

a. Subuh Berjamaah dan Masjid Mengaji untuk kegiatan ini kami bekerja sama dengan para penyuluh yang berada di Kab/Kota bahkan Gubernur dan Wakil Gubernur berbagi tugas untuk melaksanakan tugas ini diberbagai masjid yang ada di Jawa Barat.

b. Kredit Masyarakat Sejahtera atau disebut Kredit Mesra dimana Masjid dijadikan tempat ibadah sekaligus pusat pertumbuhan ekonomi melalui 
pinjaman modal untuk masyarakat sesuai syarat dan ketentuan yang berlaku.

c. Ulama Juara, Ia pun menjelaskan bahwa untuk menguatkan pondok pesantren maka harus ada peningkatan kualitas kompetensi ajengan atau ulamanya.

\section{Infrastruktur Konektivitas Wilayah}

Infrastruktur merujuk pada sistem fisik yang menyediakan transportasi, pengairan, drainase, bangunan-bangunan gedung dan fasilitas publik yang lain yang dibutuhkan untuk memenuhi kebutuhan dasar manusia dalam lingkup sosial dan ekonomi.

Program Infastruktur di Indonesia pada umumnya mengalami kemajuan. Infrastruktur menjadi program vital untuk membangun proses pembangunan secara nasional. Program infrastruktur juga dijadikan program unggulan oleh pemerintahan Jawa Barat. Infrastruktur menjadi urutan ke 6 dan skala prioritas warga Jawa Barat. Tujuan dari infrastruktur konektivitas wilayah ini dijadikan sebagai sarana penghubung antar wilayah.

Seperti yang dilansir dalam humas jabarprov bahwa Pemerintah Daerah Provinsi Jawa Barat terus berupaya meningkatkan konektivitas wilayah yang indikatornya ditandai dengan kemantapan dan aksebilitas jalan di Jawa Barat. Pemerintahan Jawa Barat membangun jalan-jalan untuk merealisasikan program tersebut.

\section{Gerakan Membangun Desa (Gerbang Desa)}

Desa dijadikan ujung tombak pembangunan untuk membangun wilayah secara nasional. Pemerintahan Jawa Barat juga membangun wilayah di wilayah hukumnya dengan membangun desa dengan program Gerbang Desa. Menurut Kartasasmita, mengatakan bahwa hakekat pembangunan nasional adalah manusia itu sendiri yang merupakan titik pusat dari segala upaya pembangunan dan yang akan dibangun adalah kemampuan dan kekuatannya sebagai pelaksana dan yang akan dibangun adalah kemampuan dan kekuatannya sebagai pelaksana dan penggerak pembangunan.

Tujuan dari pembangunan desa ini adalah untuk menyeimbangkan antara pembangunan desa dan kota. Pemprov Jabar sudah meluncurkan inovasi bernama 
Desa Juara yang memiliki tiga pilar, yakni digitalisasi layanan desa, One Village One Company (OVOC) dan Gerakan Membangun Desa (Gerbang Desa).

\section{Subsidi gratis golongan ekonomi lemah}

Ekonomi lemah (dhuafa) dalam islam juga menjadi prioritas dan perhatian.

Dalam An-nisa: 9 Allah berfirman

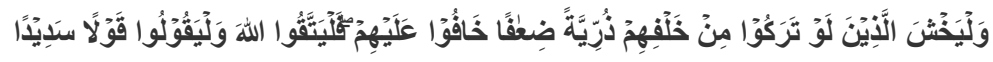

Dan hendaklah takut kepada Allah orang-orang yang seandainya meninggalkan dibelakang mereka anak-anak yang lemah, yang mereka khawatir terhadap (kesejahteraan) mereka. Oleh sebab itu hendaklah mereka bertakwa kepada Allah dan hendaklah mereka mengucapkan perkataan yang benar.

Menurut World Bank, definisi dari kemiskinan adalah kehilangan kesejahteraan. Di Jawa Barat dalam paparan RKPD BAPPEDA disebutkan bahwa periode 2016-2020 terjadi penurunan tingkat kemiskinan di Provinsi Jawa Barat. Walaupun kondisi tersebut juga menunjukkan terjadi perlambatan penurunan kemiskinan di Provinsi Jawa Barat dari target yang telah ditetapkan akibat dari kondisi makro ekonomi nasional. persentase penduduk miskin Provinsi Jawa Barat lebih rendah dibandingkan nasional sebesar 10,19 persen.

\section{Inovasi Pelayanan Publik dan Penataan Daerah}

Pemerintah Provinsi Jawa Barat akan terus mendorong 27 pemerintah daerah kabupaten/kota di Jawa Barat menghadirkan berbagai inovasi layanan pemerintahan dan pembangunan di daerahnya masing-masing. Tak hanya itu, diharapkan muncul para inovator dari daerah yang melahirkan karya-karya hebat dan besar.

\section{E. KESIMPULAN}

Kebijakan yang dibuat oleh pemerintah Jawa Barat di wilayah hukumnya telah dijalankan sesuai rencana meskipun belum $100 \%$ berjalan karena mengingat wilayah Provinsi Jawa Barat yang luas. Dari sembilan skala prioritas yang dicanangkan Pemerintahan daerah ada beberapa yang sudah berjalan dan banyak mengalami perubahan, diantaranya adalah program rutilahu, pendidikan merata, anggaran untuk masyarakat miskin, pendidikan untuk pesantren, pembekalan pegawai negeri, dan sebagainya.

Infrastruktur wilayah dengan dibangunnya jalan-jalan yang rusak juga sudah berjalan disebagian daerah. Pariwisata yang termasuk andalan pemerintahan 
Jawa Barat terus mengalami perkembangan sudah banyak tempat wisata baru di

Jawa Barat untuk menyambut kehidupan normal pasca pandemi.

\section{REFERENSI}

Abdul, Halim. 2002. Filsafat Pendidikan Islam dan Pendekatan Historis Teoris dan Praktis. Jakarta: Ciputat Pers. Hal 25.

Abuddin Nata, Perspektif Islam tentang Strategi Pembelajaran, Jakarta: Kencana, $2009,340$.

Azwar, Azrul. 2010. Pengantar Adminitrasi Kesehatan. Tangerang: Binarupa Aksara. Hal 42.

BAPPEDA Jawa Barat. Paparan RKPD 2022. 21 Maret 2020

Barreto dan Giantari. Strategi Pengembangan Objek Wisata Air Panas Di Desa Marobo, Kabupaten Bobonaro, Timor Leste. E-Jurnal Ekonomi Dan Bisnis Universitas Udayana. Halaman 34

Dunn, William N. 2013. Pengantar Analisis Kebijakan Publik. Cetakan kelima. Yogyakarta : Gajah Mada Universitas Press. Hal 117

Grigg, N. 1988. Infrastructure Engineering and Management. John Wiley \& Sons Australia, Limited.

Humas Provinsi Jawa Barat. Pemda Prov Jabar terus tingkatkan konektivitas wilayah. http://humas.jabarprov.go.id. Diakses : 8 September 2021. Pukul 10.30 WIB

Humas Provinsi Jawa Barat. Jabar Gelar Muserenbang RJMPD 2018-2023. http://humas.jabarprov.go.id/jabar-gelar-musrenbang-perubahan-rpjmd2018-2023/4028. Diunduh pada Selasa, 24 Agustus 2021. Pukul 04.45

Irjus, Indrawan. 2021. Manajemen Berbasis Sekolah. Yogyakarta: Qiara Medika. Hal 4

Islamy, M. Irfan. 2017. Prinsip-prinsip Perumusan Kebijaksanaan Negara. cet VIII. Jakarta: Bumi Aksara. Hal. 20

James, E. Anderson. 2015. Publik Policy Making. $8^{\text {th }}$ Edition. Stamford, CT: Cengage Learning.

JDIH Jabar Prov. Peraturan Gubernur Jawa Barat No. 43 Tahun 2020 Petunjuk Tehknis. https://jdih.jabarprov.go.id. Diunduh pada : Rabu, 8 September 2021. Pukul 06.38 WIB.

Jhingan L. 2013. Ekonomi Pembangunan Dan Perencanaan. Jakarta: Rajawali Pers

Kartasasmita Ginanjar. 2001. Pembangunan untuk Rakyat Memadukan Pertum buhan dan Pemerataan. Jakarta: PT. Pustaka Cidesindo. Halaman 66.

Kemenag.go.id. Pemprov Jabar bersinergi membenahi pendidikan PONTREN. https://jabar.kemenag.go.id. Diakses : 8 September 2021. Pukul 10.00 WIB. Kompas.com. Maksimalkan Layanan Kesehatan, Pemprov Jabar Luncurkan MPUS. https://regional.kompas.com. Diakses : 8 September 2021. Pukul 9:13.

Mahmud Ahmad Sa'id al-Athrasy. 2013. Hikmah di Balik Kemiskinan. Jakarta: Qisthi Press.. Hal. 1 
Nugroho, Heru. 1995. Kemiskinan, Ketimpangan dan Kesenjangan. Yogyakarta : Aditya Media.

Polit, D \& Beck, C. 2004. Nursing Reseach: Principle and Methods. Philadelphia J.B. Lippincott Campany. dalam Jurnal Keperawatan Indonesia Vol 10. No 2. Sep 2006 hal 76-80

Pramanik, Ataul Huq. 1993. Development and Distribution in Islam. Kuala Lumpur: Pelanduk Publications.

Prof. Simon Kuznets. Jhingan, 2000. Ekonomi Pembangunan dan Perencanaan. Jakarta : Rajawali Press.

Rodinelli, Dennis A. 1990. Development ProjectsAs Policy Eksperiments, an Adaptips Approach to Development Administratio. New York : Routledge. Hal 91.

Sukirno, Sadano. 2011. Makro EkonomiTeori Pengantar. Edisi ketiga. Jakarta : Rajawali Press. Hal. 331.

Supriatna. 1997. Kemiskinan : Teori, Fakta dan kebijakan. impac. Hal. 90. Tempo.co. Jawa Barat dorong daerah Inovasi Pelayanan Publik.

https://nasional.tempo.co. Diakses : 8 September 2021. Pukul 10.30 WIB

Tempo.co. Jawa Barat kembangkan 76 destinasi wisata baru berbasis alam. https://travel.tempo.co. Diakses : 8 September 2021. Pukul 9:13

Tempo.co. Pemprov Jabar fokus bangun desa. https://nasional.tempo.co/read. Diakses : 8 September 2021. Pukul 10.30 WIB 